PF 2019 (LXXIII): 495-503

\author{
JIŘÍ REJZEK \\ Ústav českého jazyka a teorie komunikace \\ Filozofická fakulta Univerzity Karlovy \\ nám. Jana Palacha 2; 11635 Praha 4 \\ tel. $(+420) 606884850$ \\ e-mail: jiri.rejzek@ff.cuni.cz
}

\title{
VÝRAZY PRO '(LIDSKOU) VLASTNOST’ V ČEŠTINĚ A JINÝCH SLOVANSKÝCH JAZYCÍCH
}

KLÍČOVÁ SLOVA: vlastnost, slovanské jazyky, sémantický vývoj

SŁOWA KLUCZOWE: cecha, języki słowiańskie, rozwój semantyczny

KEYWORDS: quality, Slavonic languages, semantic development

\section{EXPRESSIONS FOR ‘(HUMAN) QUALITY’ IN CZECH AND OTHER SLAVONIC LANGUAGES}

\begin{abstract}
The word for 'quality' is not common Slavonic; its equivalents were only formed in individual Slavonic languages relatively late. Not infrequently, more expressions of one language compete with each other in this sense, also the motivation of the words is quite varied. In this paper, I will particularly deal with the development and alterations of the words for 'quality' in Czech, Slovak and Polish, the situation in other Slavonic languages will be briefly outlined then.
\end{abstract}

ABSTRAKT: Slovo pro 'vlastnost' není obecně slovanské; jeho ekvivalenty se vytvářely až dosti pozdě na půdě jednotlivých slovanských jazyků. Často si v tomto významu konkuruje v jednom jazyce více výrazů, i motivace pojmenování bývá dosti pestrá. V příspěvku se budeme podrobněji věnovat vývoji a proměnám pojmenování pro 'vlastnost' v češtině, stručně pak nastíníme, jak vypadá situace v jiných slovanských jazycích.

Lidské vlastnosti jsou častým předmětem zkoumání slovanské kognitivní lingvistiky se zaměřením na jazykový obraz světa. Cílem tohoto příspěvku je podívat se na původ a motivaci výrazů pro (lidskou) vlastnost ve slovanských 
jazycích. Hlavní pozornost bude věnována češtině, slovenštině a polštině, stručně se zmíníme i o ostatních jazycích.

Ve staré češtině se slovo pro vlastnost (či souhrn vlastností) objevuje jako ekvivalent k lat. qualitas v podobě kakost. Zdá se, že jde o kalk vytvořený Štítným (od kaký jako qualitas od qualis 'jaký), srov. např. To, ješto kakoft slove v tělesné věci neb v duchovní, nenie v bohu: nenie bielý, nenie črný neb barvený atd. ŠtítBud. 87. Tak že by viece chléb neostal v svém bytu, jediné (ostali by) prípadkové chleba, kakofti a barvy beze všie podstaty chlebné ChelčRepl. 62a. Buoh jest bez kakofty dobrý sine qualitate bonus ROl. 2b. Nakazí se mozk a podlé kakofti barvy bude spuosoben Rhas. 30. Vedlé kakofti dýmu BřezSnář. 80. - kakoft qualitas Prešp. 20, SlovBrn. 69; z kakofti časóv pro qualitate Kladr. Esth. 16, 9; za kakoft pro qualitate HymnA. 5a (Gb II, s. 10).

Od konce 14. stol. se pak objevuje podoba jakost: yakoft quantitas Prešp. 20, SlovBrn. 70; qualitates t. j. jakosti všelijaké atd. ČČMus. 1898, 176 (ze XVI st.); - vedlé iakofti BřezSnář. 192. Zajímavé je, že vedle významu 'vlastnost' se objevuje i ve významu 'množství, velikost', tedy jako ekvivalent lat. quantitas. Přespurský slovník z konce 14 . stol. dokonce oba významy rozlišuje právě rozdílem v násloví - kakost $\times$ jakost; $\mathrm{v}$ textu je pak tento rozdíl doložen v Letopisech Trojánských 12, 1: jakost i kakost bojujících (citováno podle Jg I, 565). Stejný dvojí význam má i další ekvivalent latinských výrazů, který se ve staré češtině použíá, totiž kterakost: Buoh jest bez kterakofty veliký sine quantitate magnus ROl. 2b; rozváživše kterakoft a vážnost statkóv List. XVI stol.; aby vyznal o jisté kterakosti nebo jakosti Brikc. 94: kteraloft (sic) qualitas Cath. 176b (Gb I, s. 597).

Dnešní slovo vlastnost je ve staročeštině celkem hojně zastoupeno, ovšem v poněkud jiném významu 'vhodnost, náležitost; poměr' (MStčS 1978, s.v., Šimek 1947, s.v.), v latinsko-českých slovnících jako ekvivalent lat. species (KlarVok, SlovKlem), i když v některých kontextech se blíží dnešnímu významu - srov. Protož prvá vlastnost zákona jest, že vady má vypléti (LyraMat); neb nerozlučnost jest vlastnost manželstvie (tamtéž); poznati jistě myšlenie člověčie jestit vlastnost samého boha (Stč. textová banka). Význam bychom $\mathrm{v}$ těchto př́padech definovali spíše jako 'osobitost, charakteristický rys'.

Podobné rozložení významů pak trvá i ve stř̌ední češtině. Základním výrazem pro vlastnost je jakost, srov. ta květná jakost v krátce svůj stav musí stratit (KadlZdor 76) či její mravy, pěkné cnosti, její premilé jakosti (RosaDisc 127), kde má toto slovo právě význam 'lidská vlastnost'. Slova vlastnost se užívá ve významech 'náležitost, osobitost', srov. veliká ujma i vlasnosti i ušlechtilosti české řeči (BlahGram 69b), řidčeji 'podoba, povaha' (téžt i já [zrcadlo] jsem jasné dosti, ukazujic lidem vlastnost jejich (PaprObora F2a), nově se objevuje význam 'vlastnictví, srov. $z$ vlastnosti neb $z$ poddanosti vysvoboditi (RešSlovB SS1b), odřikám se všechněch bohatství, vlastnosti, péčování, důstojenství (BridVeč 153). Obě slova 
nalezneme v dokladu Ne že by chléb a víno po zříkání slov své jakosti a vlastnosti ztratily (ZámrPost 176a), což je zřejmě třeba chápat jako 'vlastnosti a osobitosti (náležitosti)' (k prŕkladům viz Nejedlý et al. 2012).

Také slovenština daného období zná u slova vlastnost' významy 'osobitost' a 'vlastnictví', zdá se však, že přechod k dnešnímu významu se tam uskutečnil rychleji než v češtině. HSJS (VI, s. 404) uvádí význam 'základná povahová črta človeka' jako hlavní a uvádí napr. tyto doklady: rozd’ylne osob wlastnosti jsu, wssak gediné wssech božstwý CC 1655; kdo ge krwawég nátury, této ma wlastnosti GV 1755; odrykag se náskrze nesslechétnég wlástnósti BIR 18. st. Substantiva jakost', jakovost' potom označují 'souhrn vlastností, kvalitu', např. čelo gest ssiroke dobreho prirozenj neb yakowosti KoB 1666; žaden [človek] geho yakowost nemuže gistotne oznamiti SP 1696. Kamaldulský slovník z r. 1763 potom obě slova v podobách wlásnost a gakost uvádí jako synonyma lat. qualitas.

Jungmann (V, s. 128) má jako základní význam slova vlastnost 'vlastnictví, jako další význam uvádí 'co komu vlastního přirozením nebo zvykem', německé Eigenschaft, Eigenheit, Eigentümlichkeit, tedy 'vlastnost' i 'zvláštnost, osobitost'. Přitom upozorňuje na odlišný význam slova jakost ve významu 'qualitas', ačkoliv i zde uvádí něm. ekvivalent Eigenschaft, v samotném hesle však zdůrazňuje význam německého Beschaftigheit, tedy 'povaha, jakost' (Jg I, s. 565). Je tu už tedy náběh k dnešnímu rozlišení významů - jakost jako 'kvalita, souhrn vlastnostî' a vlastnost jako 'co je komu vlastní' s jistým posunem od 'zvláštního, osobitého rysu' k 'příznačnému, charakteristickému rysu'.

Podobný vývoj vidíme i v polštině. Staropolský slovník (SStp 10, s. 248) uvádí własność, włosność, włostność (podobu s-a-je zřejmě třeba připsat vlivu češtiny, srov. Siatkowski 1996, s. 12, 45; SEJPBor, s. 704) s významy 'vlastnost, charakter, podstata' (ekvivalent latinského proprietas), dále '(osobní) svoboda', 'vlastnictví, majetek', 'vláda, panování a 'právo, přijaté mravní zásady'. Slovo jakość je doloženo ojediněle jako ekvivalent latinského qualitas (SStp 3, s. e113). I Lindeho slovník zaznamenává pro polštinu podobný stav jako pro soudobou češtinu. Slovo właściwość, které mezitím nahradilo slovo własność, je ekvivalentem něm. Eigentümlichkeit, tedy 'osobitost', zatímco jakość, jakowość je přeloženo jako Eigenschaft, tedy 'vlastnost' (L V, s. 349 a II, s. 232). Podle Jg (l.c.) Linde pro polštinu odlišuje jakość 'vlastnost' a jakowość 'souhrn vlastností, jakost', ale v jeho slovníku to takto explicitně řečeno není. Významy se nakonec v moderní polštině modifikovaly stejným zpo̊sobem jako v češtině, $v$ polštině však do toho ještě vstupuje slovo cecha, původně 'př́íznak, znak' (z německého Zeichen, srov. české cejch), které v nové polštině rovněž vystupuje ve významu 'vlastnost' (především právě 'lidská vlastnost').

Podívejme se stručně na situaci $\mathrm{v}$ dalších slovanských jazycích. Kašubština jako jazyk nejbližší polštině má $\mathrm{k}$ jednotlivým polským výrazům i podobné 
ekvivalenty - jakòsc, céch (vedle znanka) i włôscëwòsc (Gòłąbk s.v., za zprostředkování dosud nepublikované části slovníku vděčím V. Knollovi ze SLÚ AV ČR), otázkou je, nakolik byly kašubské výrazy polštinou ovlivněny. Trepczykův slovník však uvádí jako ekvivalenty p. właściwość výrazy swòjizna, znakòwizna (Trepczyk 1994, s. 324).

Obě variety lužické srbštiny mají pro 'vlastnost, jakost' výraz kajkosć, což je výraz formálně odpovídající stč. kakost. Žádné výrazy formálně odpovídající českému vlastnost či polskému właściwość se v lužičtině nevytvořily.

Naopak překvapivou podobnost najdeme v nejzápadnějším z jihoslovanských jazyků, slovinštině, kde je základním výrazem pro 'vlastnost' lastnost. Nejde přitom o přejetí z češtiny jako $\mathrm{v}$ některých jiných př́padech, ale o tvoření z praslovanského *vold-t-, které je všeslovanské kromě již zmíněné lužické srbštiny. Vedle toho se ve slovinštině uživá i výrazu svojstvo, který má význam 'vlastnost, osobitost, zvláštnost' (Pleteršnik II, s. 614) a v podobných významech ho nacházíme ve všech jihoslovanských jazycích. Za zmínku snad stojí, že v lužické srbštině má stejný lexém (swojstwo) význam 'vlastnictví, což opět potvrzuje významové propojení mezi 'vlastnictvím' a 'vlastností. Pro jakost má slovinština výraz kakovost, kvaliteta.

Srbština a chorvatština mají pro vlastnost vedle slova svojstvo také výrazy osobina, crta, zatímco pro jakost užívají kakvoća či kvaliteta. Základním výrazem pro vlastnost (i jakost) v bulharštině je kačestvo, vedle toho se pro vlastnost používá i čerta, svojstvo a osobenost (poslední výraz však znamená spíš 'zvláštnost, osobitost'). Makedonština se zde ukazuje jako určitý můstek mezi srbštinou a bulharštinou - se srbštinou ji spojuje výraz osobina (zatímco osobenost je 'zvláštnost, osobitost, svéráznost'), s bulharštinou pak výraz kačestvo ve významu 'jakost'.

Slovo kačestvo ve východní větvi jihoslovanských. jazyků je asi výpůjčka z ruštiny, kde je toto slovo doloženo již v ruské církevní slovanštině v podobě kačbstvo jako ekvivalent k řeckému poiotés (Fasmer II, 214), tedy 'jakost, povaha'. Dnešní ruské kačestvo znamená především 'jakost', ale také 'vlastnost', vedle toho se ve druhém významu užívá opět svojstvo. Zbylé východoslovanské jazyky jsou při pojmenovávání pojmu 'vlastnost' ovlivněny polštinou - základním výrazem v ukrajinštině je vlastyvist', v běloruštině ulascivasc', oba výrazy odpovídají polskému właściwość a absence ruského plnohlasí prozrazuje zřejmě přímé lexikální výpůjčky z polštiny. Stejně tak i ukrajinské jakist’ a běloruské jakasc' odpovídají polskému jakość.

Pro pojem 'vlastnost' tedy máme ve slovanských jazycích poměrně pestrou škálu výrazů. Dá se říci, že výrazy obsahující kořen kak- (jak-) mají tendenci vyjadřovat spíš význam 'jakost, souhrn vlastností, kvalita', zatímco význam 'vlastnost, charakteristický rys' obsazují výrazy, které měly původní význam 'osobitost, svébytnost, náležitost'. Mezi oběma skupinami významů je však jen malý rozdíl a významové nuance se tu často stírají. 
Z uvedeného průzkumu je zřejmé, že slovo pro 'vlastnost' není obecně slovanské; jeho ekvivalenty se vytvářely až dosti pozdě na pưdě jednotlivých slovanských jazyků. Je to samozřejmě dáno tím, že jde o značně abstraktní pojem, který v primitivnějších jazykových společenstvích neměl uplatnění. Praslovanština zřejmě výraz pro lidskou vlastnost či vlastnost obecně neměla.

\section{Seznam pramenů:}

BIR - Blosyuss, Ray vernég dussi, 18. stol.

BlahGram - Blahoslav, Gramatika česká, 1571

BridVeč - Bridel, Stůl Páně, 1660

Brikc - Brikcí z Zlicka, Práva městská, 1536

BřezSnář - Vavřinec z Březové, Snáŕ, rkp., 1471

Cath - Catholicon latino-teutonico-bohemicum, rkp., 15. stol.

CC - Cantus catholici, 1655

ČČMus - Časopis Muzea království českého

GV - Gavlovič, Walaska sskola mrawuw stodola, 1755

HymnA - Hymnár Jana z Domašína, 1429

ChelčRepl - Petr Chelčický, Replika proti Mikuláši biskupci Táborskému, okolo 1430

KadlZdor - Kadlinský, Zdoroslaviček, 1665

KladrEsth - Bible kladrubská, 2. pol. 15. stol.

KlarVok - Klaret, Vokabulář gramatický, poč. 15. stol.

KoB - Komenský, Ianua linguae latinae reserata, překlad F. Bulovského, 1666

LyraMat - Mikuláš z Lyry, Výklad evangelia sv. Matouše, poč. 15. stol.

PaprObora - Paprockého Obora, 1602

Prešp - Slovník prešpurský, konec 14. stol.

RešSlovB - Rešel, Dictionarium bohemico-latinum, 1562

Rhas - Rhazesovo ranné lékařství, 15. stol.

Rol - rkp. Knihovny v Olomouci, poč. 15. stol.

RosaDisc - Rosa, Discursus Lypirona, 1651

SlovBrn - Slovník brněnský, 3. čtvrtina 14. stol.

SlovKlem - Slovník klementinský, 1455

SP - Sprawa o krestianské powinnostj, 1696

ŠtítBud - Štítný, Řeči besední, poč. 15. stol.

ZámrPost - Zámrský, Postilla evangelická, 1592 


\section{Zkratky slovníků}

Gb - J. Gebauer, Slovník staročeský, Praha 1903-1916;

HSJS - Historický slovník jazyka slovenského, Bratislava 1981-2008;

Jg - J. Jungmann, Slovník česko-nèmecký, Praha 1834-1839;

L - S.B. Linde, Słownik jezyka polskiego, Warszawa 1807-1814;

MStčS - Malý staročeský slovník, Praha 1978;

SEJPBor - W. Boryś, Słownik etymologiczny języka polskiego, Kraków 2005;

SStp - Słownik staropolski, red. S. Urbańczyk, Kraków 1953-2002.

\section{Bibliografie}

Фасмер, М. (1964-1973). Этимологический словарь русского языка. Перевод с немецкого и дополнения О.Н. Трубачева. Москва.

Gòłąbk, E. (2011). Slownik polsko-kaszubski. Dostupné z: http://skarbnicakaszubska.pl/ wp-content/uploads/2016/11/Slownik_1-1.pdf

Nejedlý, P. et al. (2010). Lexikální databáze humanistické a barokní češtiny [online], Praha [citován stav z 17.11. 2018], dostupné na adrese http://madla.ujc.cas.cz.

Pleteršnik, M. (1894-1895). Slovensko-nemški slovar. Ljubljana.

Siatkowski, J. (1996). Czesko-polskie kontakty językowe. Warszawa.

Staročeská textová banka [online]. Ústav pro jazyk český AV ČR, v. v. i., oddělení vývoje jazyka. Verze dat 1.1.4 [cit. 7. 12. 2018]. Dostupné z: http://vokabular.ujc.cas.cz/banka.aspx?idz=STB

Šimek, F. (1947). Slovníček staré češtiny. Praha.

Trepczyk, J. (1994). Slownik polsko-kaszubski. Gdańsk. 


\title{
WYRAŻENIA SŁUŻĄCE DO OPISANIA '(LUDZKIEJ) CECHY' W JĘZYKU CZESKIM I INNYCH JĘZYKACH SŁOWIAŃSKICH
}

\author{
(Przekład skróconej wersji artykułu)
}

Słowo oznaczające 'cechę' nie jest ogólnosłowiańskie; jego ekwiwalenty tworzyły się dość późno na gruncie poszczególnych języków słowiańskich. W języku prasłowiańskim z pewnością nie było wyrazu oznaczającego ludzką cechę czy cechę jako taką.

W starej czeszczyźnie słowo oznaczające cechę (a także zespół cech) występuje jako ekwiwalent łac. qualitas w postaci kakost. Wydaje się, że chodzi o kalkę stworzoną przez Štítnego (od kaký jako qualitas od qualis 'jaki'), por. np. To, ješto kakoft slove v tělesné věci neb $v$ duchovní, nenie $v$ bohu: nenie bielý, nenie črný neb barvený atd. ŠtítBud. 87. Od końca XIV wieku pojawia się zaś postać jakost (o staroczeskich dokumentach zob. Gb I, s. 597).

Dzisiejsze słowo vlastnost 'cecha' w języku staroczeskim jest bogato reprezentowane, jednakże w trochę innym znaczeniu niż współcześnie, tj. jako 'vhodnost, náležitost; poměr' - por. pol. 'odpowiedniość, stosowność; stosunek' (MStčS, s.v.), w słownikach łacińsko-czeskich jako ekwiwalent łac. species (KlarVok, SlovKlem), choć w niektórych kontekstach zbliża się do dzisiejszego znaczenia - por. Protož prvá vlastnost zákona jest, že vady má vypléti (LyraMat XVII C 20; 15); neb nerozlučnost jest vlastnost manželstvie (ibidem).

Podobny rozkład znaczeń można zauważyć także we wczesnym okresie nowożytnym języka czeskiego. Podstawowym wyrazem oznaczającym cechę jest jakost, por. její mravy, pěkné cnosti, její premilé jakosti (RosaDisc 127), gdzie słowo to ma właśnie znaczenie 'lidská vlastnost' - pol. 'cecha ludzka'. Słowo vlastnost używane jest w znaczeniach 'náležitost, osobitost' (pol. 'stosowność, odrębność'), por. veliká ujma i vlasnosti i ušlechtilosti české řčci (BlahGram 69b), rzadziej 'podoba, povaha' (pol. 'postać, charakter', por. téžt' i já [zrcadlo] jsem jasné dosti, ukazujíc lidem vlastnost jejich (PaprObora F2a), pojawia się też nowe znaczenie 'vlastnictví' (pol. 'własność), por. odříkám se všechněch bohatství, vlastnosti, péčování, dưstojenství (BridVeč 153). Oba słowa można znaleźć w dokumencie Ne že by chléb a víno po zříkání slov své jakosti a vlastnosti ztratily (ZámrPost 176a), co z pewnością należy rozumieć jako 'vlastnosti a osobitosti (náležitosti)' - pol. 'cechy i odrębności (stosowności)' - por. Nejedlý i in., 2010.

Również język słowacki badanego okresu notuje przy słowie vlastnost' znaczenia 'osobitost' (pol. 'odrębność), 'vlastnictví' (pol. 'własność'), wydaje się jednak, że przejście do dzisiejszego znaczenia odbyło się tam szybciej niż w języku czeskim - por. dokumenty w HSJS VI, s. 404.

W słowniku Jungmanna (V, s. 128) jako główne znaczenia słowa vlastnost poświadczono 'vlastnictví' (pol. 'własność), kolejne znaczenie to: 'co komu vlastního přirozením nebo zvykem' (pol. 'co komu własnego z natury czy przyzwyczajenia'), niemieckie Eigenschaft, Eigenheit, Eigentümlichkeit, czyli 'vlastnost' (pol. 'cecha') i 'zvláštnost, osobitost' (pol. 'osobliwość, odrębność). Jednocześnie zwraca się uwagę na odmienne znaczenie słowa jakost w znaczeniu 'qualitas', a w samym haśle podkreślono znaczenie niemieckiego Beschaftigheit, czyli 'povaha, jakost' (pol. 'charakter, przymiot') - por. Jg I, 565. Jak widać, już tutaj roz- 
poczyna się dzisiejsze rozróżnienie znaczeń - jakost jako 'kvalita, souhrn vlastnostî' (pol. 'jakość, zespół cech') i vlastnost jako 'co je komu vlastní' (pol. 'co jest dla kogo własne’) z pewnym przesunięciem od 'zvláštního, osobitého rysu' (pol. 'specjalnej, osobistej cechy' do 'príiznačnému, charakteristickému rysu' (pol. 'typowej, charakterystycznej cechy').

Podobny rozwój widzimy również w języku polskim. W Słowniku staropolskim (SStp 10, s. 248) znajdziemy własność, włosność, włostność (postać z -a- należy z pewnością przypisać wpływowi czeszczyzny - por. Siatkowski 1996, s. 12, 45 i in.; Boryś 2005, s. 704) ze znaczeniami 'vlastnost, charakter, podstata' (pol. 'właściwość, charakter, kwintesencja'), stanowiącymi ekwiwalent łacińskiego proprietas, a także '(osobní) svoboda' (pol. '(osobista) wolność'), 'vlastnictví, majetek' (pol. 'własność, majątek'), 'vláda, panování' (pol. 'władza, panowanie’) i 'právo, přijaté mravní zásady' (pol. 'prawo, przyjęte zasady moralne’). Słowo jakość pojawiło się jedynie jako ekwiwalent łacińskiego qualitas (SStp 3, s. 113). Również słownik Lindego rejestruje dla języka polskiego podobny stan jak dla ówczesnej czeszczyzny. Słowo właściwość, które tymczasem zastąpiło słowo własność, jest ekwiwalentem niem. Eigentümlichkeit, czyli 'osobitost' (pol. 'odrębność), podczas gdy jakość, jakowość oznacza Eigenschaft, czyli 'vlastnost' (pol. 'cecha') - por. L V, s. 349; II, s. 232. Znaczenia te w końcu zmodyfikowały się w taki sam sposób jak w języku czeskim, w polszczyźnie dochodzi do tego słowo cecha, pierwotnie príznak 'znak' (pol. 'objaw, znak'), z niemieckiego Zeichen - por. czeskie cejch, które w nowej polszczyźnie również występuje w znaczeniu 'vlastnost' (pol. 'cecha').

Z pobieżnego oglądu sytuacji w pozostałych językach słowiańskich wynika, że w języku serbołużyckim na oznaczenie 'vlastnost, jakost' (pol. 'cecha, przymiot') jest używany wyraz kajkosć - formalnie odpowiadający staroczeskiemu kakost. Nie ma natomiast żadnych leksemów formalnie odpowiadających czeskiemu słowu vlastnost czy polskiemu właściwość.

Zadziwiające podobieństwo znajdujemy w języku słoweńskim, gdzie podstawowym określeniem dla 'vlastnost' (pol. 'cecha') jest vlastnost. Nie mamy tutaj do czynienia z zapożyczeniem z czeszczyzny, jak w niektórych innych przypadkach, lecz ze słowem, które powstało niezależnie. Oprócz tego w języku słoweńskim używany jest również wyraz svojstvo, który ma znaczenie 'vlastnost, osobitost, zvláštnost' (pol. 'cecha, odrębność, osobliwość) - por. Pleteršnik II, s. 614; w podobnych znaczeniach występuje we wszystkich językach południowosłowiańskich. Warto wspomnieć, że w języku serbołużyckim ten sam leksem (swojstwo) ma znaczenie 'vlastnictví' (pol. 'własność'). Na 'jakość' język słoweński ma wyrażenia kakovost, kvaliteta.

Języki serbski i chorwacki posiadają dla określenia cechy oprócz słowa svojstvo również rzeczowniki osobina, crta, podczas gdy dla jakości używane są kakvoća i kvaliteta. Podstawowym wyrazem opisujących cechę (i jakość) w języku bułgarskim jest kačestvo; oprócz tego w odniesieniu do cechy stosowane są także rzeczowniki čerta, svojstvo i osobenost (ostatni wyraz oznacza jednak raczej 'zvláštnost, osobitost' - pol. 'osobliwość, odmienność). Język macedoński jawi się tu jako swego rodzaju pomost między językiem serbskim i bułgarskim - z serbskim łączy go słowo osobina (podczas gdy osobenost 'zvláštnost, osobitost, svéráznost' - pol. 'osobliwość, odmienność, odrębność'), a z bułgarskim kačestvo w znaczeniu 'jakost' - pol. 'jakość.'

Słowo kačestvo we wschodniej gałęzi języków południowosłowiańskich jest najpewniej pożyczką z języka rosyjskiego, gdzie pojawia się już w ruskiej wersji języka 
starocerkiewnosłowiańskiego $\mathrm{w}$ postaci kačbstvo jako ekwiwalent greckiego poiotés (Fasmer II, s. 214), czyli 'jakost, povaha' (pol. 'jakość, charakter'). Dzisiejsze rosyjskie kačestvo oznacza przede wszystkim 'jakost' (pol. 'jakość), ale także 'vlastnost' (pol. 'cecha'), oprócz tego w drugim znaczeniu używane jest ponownie svojstvo. Nazewnictwo pojęcia 'vlastnost' (pol. 'cecha') w pozostałych językach wschodniosłowiańskich najpewniej pozostaje pod wpływem polszczyzny - podstawowym określeniem w języku ukraińskim jest vlastyvist', w białoruskim ulascivasc', oba określenia odpowiadają polskiemu właściwość; brak rosyjskiego pełnogłosu zdradza pewne bezpośrednie pożyczki leksykalne z języka polskiego. Podobnie także ukraińskie jakist’ i białoruskie jakasc’ w polszczyźnie mają swój odpowiednik jakość.

Dla określenia pojęcia 'vlastnost' (pol. 'cecha') w językach słowiańskich znajdujemy zatem stosunkowo bogaty repertuar określeń. Można powiedzieć, że określenia posiadające rdzeń kak- (jak-) mają tendencję do wyrażania raczej znaczenia 'jakost, souhrn vlastností, kvalita' (pol. 'jakość, zespół cech'), podczas gdy znaczenie 'vlastnost, charakteristický rys' (pol. 'cecha, charakterystyczny rys') niosą wyrazy, które miały pierwotne znaczenie 'osobitost, svébytnost, náležitost' (pol. 'odmienność, niezależność, stosowność'). Pomiędzy dwoma grupami znaczeń jest jednak tylko niewielka różnica, a znaczeniowe niuanse często się zacierają. 